\title{
Struggles against Bilateral FTAs: Challenges for Transnational Global Justice Activism
}

\begin{abstract}
AZIZ CHOUDRY
McGill University, Canada

ABSTRACT The past decade has seen major movements and mobilizations against the newer crop of bilateral free trade and investment agreements being pursued by governments in the wake of the failure of global (World Trade Organization) and regional (e.g. Free Trade Area of the Americas) negotiations, and the defeat of an attempted Multilateral Agreement on Investment in the 1990s. However, in spite of much scholarly, non-governmental organization (NGO) and activist focus on transnational global justice activism, many of these movements, such as the major multi-sectoral popular struggle over the recently-concluded US-Korea Free Trade Agreement, are hardly acknowledged in North America and Europe. With a shift in emphasis pushing liberalization and deregulation of trade and investment increasingly favouring lowerprofile bilateral agreements, this article maps the resistance movements to these latest shifts in global free market capitalist relations and it discusses the disconnect between these (mainly Southern) struggles and dominant scholarly and NGO conceptions of global justice and the global justice movement as well as questions of knowledge production arising from these movements.
\end{abstract}

\section{Introduction}

On November 13, 2011, tens of thousands of workers belonging to the Korean Confederation of Trade Unions (KCTU), farmers, and others took to the streets against the ratification of the US-South Korea free trade agreement (FTA) by Korean lawmakers after US Congress approval (Hankyoreh, 2011). The agreement, which some view as the most far-reaching of its kind to be signed since the North American Free Trade Agreement (NAFTA), was finally passed in the Korean National Assembly later that month, amidst continuing protests. Yet despite major mass mobilizations sustained over several years by Korean social movements, there was little awareness of this 
in North America in media or activist networks associated with the "global justice movement" which had emerged over the past two decades from rising opposition to free trade and investment agreements. As a Korean activist had noted five years earlier, it seemed that "for the World Trade Organization (WTO) resistance, it is easier to gather people across countries to mobilize together. But with FTAs, we are struggling on our own." (Participant of Fighting FTAs international strategy workshop, July 2006, Bangkok).

This article critically discusses the spread of FTAs following the breakdown of multilateral (WTO) and regional (e.g., FTAA) negotiations, and the rise in social movement activism against these agreements. A considerable body of scholarship (e.g., Bandy \& Smith, 2005; Day, 2005; Eschle \& Maiguashca, 2010; Goodman, 2002; Juris, 2008; McNally, 2002; Novelli \& Ferus-Comelo, 2010; Polet \& CETRI, 2004; Reitan, 2007; Starr, 2000) has investigated popular struggles against capitalist globalization, including campaigns against the World Bank, International Monetary Fund (IMF), WTO and Free Trade Area of the Americas (FTAA) which are often referred to as the global justice movement. Yet relatively little attention has been paid to numerous mass movements against bilateral free trade and investment agreements (FTAs) which have emerged more recently. Moreover, despite a multitude of such movements and mobilizations against FTAs, particularly (though not exclusively) in the Third World, the transnational NGO/activist networks that have actively contested the WTO and FTAA have largely failed to connect such struggles with each other, and are largely inconsequential in relation to anti-FTA activism. There has been a disconnect between major mobilizations against FTAs and established NGO networks on globalization, which have generally been slow to react or seriously address the bilateral deals. Indeed, some of these NGOs have issued triumphalist statements responding to the state of WTO talks suggesting that neoliberalism is on the defensive, thus overlooking the commitments being made in FTA negotiations (e.g., IATP, 2008; Menotti, 2008). However, as I outline, connections are slowly being made between movement activists fighting FTAs, and an important feature of such linkages is the production and sharing of knowledge arising from social movements themselves. I illustrate the importance of building upon, learning from, and sharing knowledge produced incrementally in these social struggles against global capitalism.

The 1999 mobilizations in Seattle confronting that year's WTO Ministerial meeting which had aspirations to launch a new round of global trade negotiations was viewed by many in the North as the birth of the global justice movement. Direct action-oriented groups and people's movements such as Peoples' Global Action (PGA) (Juris, 2008; Reitan, 2007; Wood, 2005), the international small and peasant farmers' movement network La Via Campesina (Desmarais, 2007; Reitan, 2007), and the NGO-dominated Our World is Not for Sale network arose during the 1990s or the start of this century to coordinate and network transnational ${ }^{1}$ opposition to the WTO (Reitan, 2007). Yet claims of newness surrounding "globalization" and "anti-globalization" obfuscated the fact that in many contexts, particularly 
in the Third World, longstanding resistance to neoliberalism in its different manifestations has spanned several decades (Choudry, 2008, 2010; Flusty, 2004; McNally, 2002; Motta \& Nilsen, 2011) including opposition to free trade agreements.

This article is informed by Bevington and Dixon's (2005) notion of "movement-relevant research," as well as the author's engagement in activism, education and research in struggles against bilateral FTAs since the 1990s. Bevington and Dixon note that just as few activists read social movement theory, so too important debates inside movement networks often do not enter the scholarly literature about social movements. They contend that social movement scholars do not have a monopoly on theory about movements. They call for recognition of existing movement-generated theory and of dynamic reciprocal engagement by theorists and movement activists in formulating, producing, refining and applying research. They hold that: "[m]ovement participants produce theory as well, although much of it may not be recognizable to conventional social movement studies. This kind of theory both ranges and traverses through multiple levels of abstraction, from everyday organizing to broad analysis" (p. 195). In situating my analysis in this way, I concur with Flacks (2004) and Bevington and Dixon's (2005) critiques of the shortcomings of much social movement theory as being driven by attempts to define and refine theoretical concepts which are likely to be "irrelevant or obvious to organizers" (Flacks, 2004, p. 147). In his work on knowledge and learning in social activism, Holst (2002) uses the term "pedagogy of mobilization" to describe

the learning inherent in the building and maintaining of a social movement and its organizations. Through participation in a social movement, people learn numerous skills and ways of thinking analytically and strategically as they struggle to understand their movement in motion ... . Moreover, as coalitions are formed people's understanding of the interconnectedness of relations within a social totality become increasingly sophisticated. (pp. 87-88)

Scholars who seek to understand social movement and NGO networks need to attend to questions coming out of social movements and activist research in regard to power dynamics and the valuing of certain forms of knowledge. These questions are often based on sophisticated macro and micro analyses of what, to an outsider, might seem a baffling network of relations, and shifting power dynamics. This is not to argue that evaluation and analysis from the standpoint of being embedded in activism is necessarily rigorous or adequate. Reflexivity is crucial when starting from, engaging with, and analyzing activist knowledge(s). In a similar vein, Foley (1999) writes that the

process of critical learning involves people in theorizing their experience: they stand back from it and reorder it, using concepts like power, conflict, structure, values and choice. It is also clear that critical learning is gained informally, through experience, by acting and reflecting on action, rather than in formal courses. (p. 64) 
Many scholarly, NGO and activist accounts pay inadequate attention to the significance of low-key, long-haul political education and community organizing work, which goes on underneath the radar, as it were. Yet, as I will argue, the knowledge being produced in social movements resisting bilateral free trade and investment agreements constitutes an important conceptual resource for contemporary and future struggles for social and economic justice.

\section{Challenges for Opponents of Bilateral Free Trade Agreements}

Mobilizations against bilateral FTAs have taken place in many countries, yet the relatively well-known transnational $\mathrm{NGO}$ /activist networks which have formed around the WTO such as Our World Is Not For Sale, and regional networks such as the Hemispheric Social Alliance (in the Americas) have not played significant roles in these. Indeed, for the most part, there appears to be a knowledge, strategic, and action disconnect between these networks and recent/current struggles against FTAs. The trajectory of transnational networks contesting free trade that has accompanied mobilizations against the WTO operates on a different track from the locally grounded struggles against FTAs, which have often been quite isolated from each other. Despite the commonalities of these agreements, and the fact that activists in, for example, Thailand, South Korea, and Colombia have simultaneously campaigned against deals with the US, there has been little opportunity to learn from each other's struggles. Given the fact that the US essentially modifies its deals from a template, and yet details are shrouded in secrecy during negotiations, analysis of texts of already concluded agreements has been important in generating critical understandings of the exact nature of the disciplines in current FTA negotiations. Because of their very nature, bilateral deals pose some specific challenges for educating, sharing knowledge, and mobilizing transnational networks and alliances against capitalist globalization. This article will also outline specific challenges for education, knowledge production/sharing and mobilization campaigns against bilateral free trade and investment agreements in comparison to activism targeting more established global agreements and institutions such as the WTO, the World Bank and the IMF.

9/11 and the "war on terror" have been used to justify renewed militarization and war, as well as various forms of domestic state intervention in the US economy. Meanwhile, repressive domestic national security and immigration legislation is being ratcheted up in many countries, North and South (Boron, 2005; Flesher Fominaya \& Wood, 2011; Mathew, 2005; Petras \& Veltmeyer, 2003; Thobani, 2007; Tujan, Gaughran \& Mollett, 2004). A number of major political and economic figures, such as former US Trade Representative (now World Bank President) Robert Zoellick (2001) disingenuously suggested intellectual connections between "terrorists" and opposition movements against neoliberalism, while insisting that further trade and investment 
liberalization (by the USA's trading partners, at least) was the most effective way to fight "terror." This has had worldwide consequences for the political space in which NGOs and global justice movements exist. Some NGOs, particularly in North America and Europe, urged people to abandon direct action tactics and more confrontational positions. Debates within networks in North America and Europe regarding diversity of tactics and the parameters of direct action in mobilizations continued, but often with an air of caution and self-censorship after 9/11 (Kinsman, 2006; McNally, 2002; Petras $\&$ Veltmeyer, 2003). In June 2010, this dynamic again played out in the major mobilizations and state repression around Toronto's G-20 protests. The momentum behind major mobilizations against meetings of the World Bank/IMF, G8, WTO, the Summit of the Americas ${ }^{2}$, the World Economic Forum and other conferences of economic and political elites, mainly in the North, that carried from Seattle into late 2001 faltered somewhat after 9/11. For Petras and Veltmeyer (2003), after 9/11, the divisions between NGOs and labour unions calling for moderate reform of the system, and anticapitalists or anti-imperialists seeking radical changes "seriously deepened, creating a fundamental rift within the [antiglobalization movement], with an increasing intolerance for radical change and confrontationalist politics" (p. 228). Nonetheless, such mobilizations - and the cycle of alternative NGO/ civil society summits have continued, often on a smaller scale, as have questions as to how connected these mobilizations were with mass social movements or everyday resistance against capitalist exploitation, and just how representative they were of the most marginalized voices of the societies for whom they sometimes claimed to speak (Hewson, 2005; INCITE! Women of Color Against Violence, 2007; Martinez, 2000; Prashad, 2003). In the North, much of the momentum and focus directed against the institutions (and their cyclical meetings) most closely identified with the promotion and maintenance of capitalist globalization has been channelled into anti-war movements (Solnit, 2004; Wood, 2004).

\section{Global Geopolitics, Faster and Deeper Free Trade and Investment}

While attempts to link commitments to further advance economic liberalization under the WTO with support for the war on terror failed to translate into tangible results in that arena since 2001, the bilateral FTA strategies, in particular, those of the US and EU, have clearly been as geopolitically driven as they have been motivated by narrow economic concerns. The EU's current FTAs based on the 2006 "Global Europe" vision insists that parties (e.g., India, Korea and ASEAN) sign a Political Cooperation Agreement before an FTA. FTAs often have little to do with trade and much to do with securing spheres of political influence and control. Access to natural resources such as oil, gas, agrofuels, minerals and biodiversity can be seen as significant in terms of both economic aspects as well as their geopolitical implications. Energy security is emerging as an important element in the FTA strategies of 
countries like Japan, China, the EU and the USA, with separate chapters of FTAs between Japan and Indonesia and Japan and Brunei guaranteeing the Japanese government a supply of gas and oil, for example.

As Sidney Weintraub (2003), of the Centre for Strategic and International Studies in Washington, D.C., puts it:

The sense that is now being conveyed around the world is that US policy is to sign free trade agreements with other countries only if they are prepared to adhere to US foreign policy positions. An FTA, in other words, is not necessarily an agreement in which all parties benefit from trade expansion, but rather a favor to be bestowed based on support of US foreign policy."

There are few signs that the current US Administration is taking a substantively different direction on trade policy. The latest global economic crisis has led many people, perhaps most recently symbolized by the Occupy movement/ mobilizations, to question the claimed benefits of free market capitalism.

Initially seen as a default for slow-moving WTO negotiations, observers and activists came to see the bilateral FTAs as a preferred option. Transnational capital has always forum-shopped to get what it wants in terms of international regulatory frameworks enforcing protection of investment and property rights (Kelsey, 1999). Through FTAs, it is possible to isolate and divide governments outside of a forum where they could on some level band together to resist demands of Northern governments within the WTO. Critics often suggest that the FTA process constitutes more of an imposition by a larger power than a real negotiation. Like WTO agreements, and given their lower profile, perhaps more so, they are negotiated in virtual secrecy, with negotiating texts routinely unavailable for public scrutiny in either country until it is much too late, or, in some cases, not even available for a significant period of time after the agreement has taken effect. Governments of smaller countries face negotiations fatigue when overstretched and underresourced officials have to deal with agreements with multiple countries, bilaterally, regionally, and multilaterally.

Former EU trade commissioner and current Director-General of the WTO, Pascal Lamy said of EU trade policy: "We always use bilateral FTAs to move negotiations beyond WTO standards. By definition, a bilateral trade agreement is "WTO plus." Whether it's about investment, intellectual property rights, tariff structure or trade instrument, in each bilateral FTA we have the "WTO plus" provision" (Jakarta Post, 2004). Bilateral agreements typically allow for deeper and faster levels of liberalization and deregulation than could be achieved in the WTO, ("WTO-plus" provisions) and specific measures and policies could be targeted with more precision. FTAs often break new ground. As governments commit to standards of liberalization that go further than the WTO through FTAs, this has implications for negotiating positions in multilateral trade talks should WTO talks get more momentum: countries will not be able to stand up to demands from Northern governments for WTO expansion when they have already signed onto WTO-plus commitments bilaterally. Bilaterally, it is sometimes easier 
to set precedents on a range of issues which can then at some point be taken into multilateral arena. Compliance with WTO agreements has been hard for many countries, but bilateral deals with WTO-plus provisions are even tougher. Through FTAs and bilateral investment treaties (BITs), EU and US trade negotiators push governments into going further and faster in adopting what are essentially corporate wish lists on areas such as intellectual property (further endangering access to treatment to millions of people living with HIV/AIDS and other life-threatening diseases, undermining traditional agriculture by imposing agribusiness monopoly rights on areas such as seeds, and expanding patent protection over all life forms), financial liberalization, and issues (e.g., government procurement and investment) which have been kept out of WTO negotiations or severely limited in their scope due to Third World governments' opposition to industrialized government demands. US agribusiness and pharmaceutical corporations are both the scripters and cheerleaders of TRIPs-plus provisions. For example, Monsanto (2004) urged US trade negotiators to seek an end to Thailand's moratorium on large-scale field trials of genetically-modified (GM) crops either "in a parallel fashion with the FTA negotiations or directly within the context of the negotiations." Monsanto (2004) said that

in the current context of free trade...it is imperative that the US work with Thailand to eliminate the current barriers to biotechnology-improved crops and establish a science-based regulatory system - including field trials of new crops - consistent with their international trade obligations in order to bring the benefits of these products to market in Thailand and to further promote consistent access to American agricultural technologies and products.

Former Thai Prime Minister Thaksin Shinawatra announced his intention to reverse Thailand's moratorium on GM field trials (which came into effect after pressure from farmers and consumer groups in April 2001). While he and his Cabinet were forced to uphold the moratorium after Thai farmers, Buddhist organizations, consumers and anti-GMO activists protested, US and Monsanto officials, who seek to make Thailand its regional base for GM Roundup-Ready corn and Bt corn, continue to have the moratorium in their sights in the context of a potential renewal of FTA talks.

BusinessEurope (formerly the Union of Industrial and Employers' Federations of Europe-UNICE) states:

Given the increasingly important role of services in EU exports, all future FTAs must ensure comprehensive liberalization of key sectors including financial services, telecommunications, professional and business services and express delivery services...The EU has a comparative advantage across the board in services and needs to ensure that this advantage is pressed home in future FTAs. (UNICE, 2006) 


\section{Bilateral Investment Threats: Popular Resistance Against Corporate Power}

As South Korean activists and commentators have noted, a major concern for the newly-minted US-Korea FTA is its investor-state dispute system. Many FTAs and BITs contain broad definitions of "investment" which throw the door wide open for disgruntled corporations based in one signatory country to take a case against the other signatory government to a binding disputes tribunal. Such disputes are fought out behind closed doors in arbitration proceedings at the World Bank's International Centre for the Settlement of Investment Disputes (ICSID). Thus far, these have often related to conflicts after the privatization of state-owned enterprises and public utilities such as water, but could extend to include almost anything. These have already become flashpoints for popular resistance.

Azurix, a former subsidiary of Enron won a bid to run the privatized water and sewage system for 2.5 million people in parts of Buenos Aires province, Argentina, in May 1999. Bahia Blanca residents complained that their water smelt bad and looked brown, while regulators considered sanctions against Azurix for very low water pressure. After the water supply was found to be contaminated, health authorities warned people not to drink or bathe in the water. The local regulating agency forced the company to deliver free bottled water to those affected, not to charge for a period when the water was of poor quality, and fined Azurix for breach of contract. In October 2001, Azurix stated that it would withdraw from the contract, complaining that the province would not let it charge rates according to the tariff specified in the contract and would not deliver infrastructure. The province rejected the termination notice. Then, under a 1991 US-Argentina bilateral investment treaty, Azurix took Argentina's bankrupt government to binding arbitration at ICSID, seeking US \$550 million. Azurix said that the authorities' actions amount to interference with its investment. In July 2006, ICSID awarded Azurix US \$165 million against Argentina, although the government has thus far refused to pay, despite threats from the current US administration.

The popular struggle against the privatized water system of Cochabamba, Bolivia, is a potent symbol of resistance against neoliberalism and privatization. This followed Aguas del Tunari (affiliate of US water corporation Bechtel) sharply increasing prices. But after the privatization was reversed, the water system handed back to the public, and it was forced to leave Bolivia, Aguas del Tunari/Bechtel lodged a request for arbitration against Bolivia at ICSID. It sought US \$50 million, claiming as expropriated investment the millions of dollars in potential profits it had hoped to make. (For the same amount, 125,000 Bolivian families without access to water could have been connected.) The company turned to a 1992 BIT between Holland and Bolivia. While it was establishing its operations in Cochabamba, Bechtel was filing papers to shift its subsidiary's corporate registration to Holland from the Cayman Islands. After international protests and pressure, at the end of 2005, Bechtel abandoned its claim against Bolivia. 


\section{Challenges for Resistance Movements against FTAs}

Although these bilateral deals are being signed and implemented in many countries, the focus of many international development and advocacy NGOs and trade union networks critical of free trade often seems to remain on the multilateral talks at the almost moribund WTO. There has been some belated focus on EPAs being signed between the EU and African, Caribbean, and Pacific countries among European and Australasian NGOs but relatively few connections have been made with local grassroots struggles against these agreements (Canterbury, 2010). It has been difficult to coordinate nationallevel opposition to EU EPAs, and much of the international campaign work on this has been driven by Northern-based NGOs which have had varying levels of connection with social movements. Conceptually, this weakness can partly be attributed to these organizations' overemphasis on the WTO, and a failure to take a clear stance against neoliberal capitalism, with a spectrum of platforms calling for anything between mild reform to complete rejection, coupled with a funding and institutional focus which tended to prioritize these institutions which were traditional targets of mobilizations.

While many of the stronger campaigns against FTAs build upon and draw from the experience of mobilization against the WTO, FTAA, and other neoliberal reforms at international and domestic levels, the lower profile of these deals has allowed negotiations to take place well under the radar of many activist movements and organizations. Some of the largest and most militant mobilizations against capitalist globalization in recent years have been anti-FTA protests, for example in Korea, where street protests against the recently concluded FTA with the US numbered in the tens of thousands regularly, and in CAFTA (US-Dominican Republic-Central American Free Trade Agreement) countries (for example, 200,000 demonstrated in San Jose, Costa Rica on February 26, 2007 against CAFTA). And yet in spite of the growth of the global justice network, these mobilizations have attracted relatively little awareness or solidarity in North America. The question is often asked how to maximize leverage/opposition against these agreements by cooperating with activists in the other signatory country, but there has been very little sustained joint activism in this regard, notwithstanding the scale and political impact of anti-FTA movements outside of Europe and North America.

In at least two cases, in Ecuador (Guttierez) and Thailand (Thaksin Shinawatra), anti-FTA movements and sentiments have contributed to overthrowing governments. Subsequently, after popular pressure led to the cancellation of Occidental Petroleum's oil extraction contract in Ecuador, the proposed FTA with the US was effectively scuttled. The geopolitical aspects of these deals, such as the US-Korea FTA, and US foreign policy in Latin America, both influence and become important mobilization targets in themselves. In Korea, opposition was related to older struggles (and the knowledge/conceptual resources which they generated) against US domination and military bases. By comparison with multilateral talks, such 
aspects have been in clearer focus in bilateral FTA struggles because of the close attention paid to other aspects of foreign affairs linkages with the other signatory government.

In many ways popular resistance to the Chile-Korea FTA set the stage for an even larger phase of mobilization against Korea's FTA with the US. Even before the fight against the Chile and US FTAs, Korean social movements had mobilized against the imposition of neoliberal reforms since the 1980s, whether imposed by Seoul, or, after the 1997-1998 economic crisis, by the IMF. Korea-Chile FTA negotiations began in 1998 and a deal was eventually concluded in 2003. Although the agreement was quite comprehensive (including services, investment, and other areas), it was its agriculture provisions, and particularly the implications for Korea's domestic fruit growers, that were the focus of opposition in Korea. Protests were frequently met with police violence, but helped to repeatedly delay ratification. While over $50 \%$ of Korea's lawmakers promised that they would oppose the FTA, they ratified it. From this experience, the farmers' movement, the Korean Peasant League (KPL) drew two lessons for future FTA fights: firstly, a struggle by small farmers alone ( $10 \%$ of Korea's population) would not lead to victory. The majority of the population were made to believe that sacrifice of the farmers was a necessary evil to achieve economic growth. Secondly, one cannot rely solely on parliamentarians, since despite all the mobilizations, the government ratified the deal anyway. So KPL learnt that it is vital to build a mass struggle with other sectors to defeat current and future FTAs. Korean farmers, unsurprisingly, were at the forefront of struggles against the FTA with the USA.

The Korean resistance against the US-Korea FTA has been a major multisectoral struggle, illustrating the importance of strong national movements in the context of cross/binational networks against a deal. While there has been a strong movement in Korea, there has been far less social movement activism in the US. There were some joint actions and statements by Korean and US unions against the FTA, and Korean protest expeditions to the USA during negotiating rounds, but little sustained focus in US. Closer to the ratification dates by the two respective governments, there was some campaigning in the US, including by progressive Korean-Americans, to stop the agreement, but no major movement mobilizations as had been seen in opposition to NAFTA, the FTAA or the WTO. Similarly a small symbolic protest action in Brussels was held against the EU-Korea FTA, but was more or less a one-off action. Just as there is a great diversity in positions, ideologies, perspectives and tactics among opposition movements against the WTO, so too, we can find among opposition to bilateral FTAs those who call for reform of these agreements (largely major trade union bureaucracies and NGOs in North America, Europe and Australasia) and those who reject these agreements altogether. NGO technical policy analyses of these agreements, along with the Bretton Woods institutions and other processes are often detached from political economy/geopolitical factors, and lack a systemic critique of capitalism and imperialism which views that all of these institutions, 
agreements and processes_-global regional, subregional, bilateral, national and subnational (i.e. state/province/municipal level) necessitate oppositional responses.

Compartmentalized approaches to addressing capitalist globalization which do not confront the systemic nature of capitalism can only be of limited effectiveness. For many NGO campaigns, this compartmentalization occurs around issues (e.g. agriculture, services), regional or countryspecific priorities, sectors (women, workers, farmers, Indigenous Peoples) and institutions and agreements (WTO, FTAA, etc.) without a broader underlying framework of analysis necessarily informing action against global capitalism per se. This tends towards a rather fragmented analysis. Certainly, in some anti-FTA struggles, particular aspects of these agreements attract more attention than others, such as intellectual property provisions of the US-Thailand agreement, and the toxic waste dumping provisions of the Japan-Philippines Economic Partnership Agreement, but the most vibrant and sustained anti-FTA mobilizations have seen broad fronts of opposition grow through an understanding of the comprehensive threats posed by these agreements. For example, movements of people living with HIV/AIDS in Thailand found common cause and forged alliances with farmers because of the intellectual property chapter in the proposed US-Thai FTA. Meanwhile, the Korean government's removal of the film quota (to promote Korean films) as part of FTA negotiations, and commitments to further liberalize Korean agriculture brought film actors, directors, and producers together with farmers and trade unionists in the streets against the US-Korea FTA.

On the other hand, in North American and European campaigns on FTAs, there has been relatively little mass mobilization or awareness. Although a somewhat more broadly-framed $\mathrm{NGO}$ /trade union campaign against the Canada-EU Comprehensive Economic and Trade Agreement (CETA) picked up some momentum in 2011, positions of NGOs and trade unions have tended to focus on rather narrow platforms such as the Canadian Autoworkers Union focus against the proposed Canada-Korea FTA because of threats to the Ontario auto assembly sector and Canadian labour/NGO framings of the Canada-Colombia FTA agreement around human rights in Colombia. Such conceptualizations of these agreements run the risk of obscuring broader and deeper instruments of neoliberalism which impact the lives of peoples in both signatory countries, and do not prioritize building broader understandings and movements against these agreements.

\section{Building Campaign Resources to Support Movements against FTAs}

Given the challenges to organizing cross-nationally, a major concern among some opponents of FTAs has been facilitation of the sharing of knowledge, research, analysis and experience. In 2004, a number of organizations ${ }^{3}$ initiated a collaborative website to support peoples' struggles against bilateral free trade and investment agreements http://www.bilaterals.org. 
bilaterals.org is an open-publishing site where people fighting bilateral trade and investment agreements exchange information and analysis and build cooperation. Those campaigning against bilateral deals had found it hard to connect with others around the world to share analysis and develop broader and complementary strategies. By early 2008, the website was attracting around 200, 000 hits a month. It has been used to leak draft negotiating texts which have otherwise not been made public, such as a draft IPR chapter of the US-Thailand FTA (The Nation, 2006), which was important for Thai activists to highlight. It is also a forum for activists to directly alert others about developments in their struggles, not least during intense periods of mobilization and state repression in Korea and Costa Rica in 2007 and 2008, mass mobilizations in Peru against proposed FTAs with the EU and the USA, and a wave of anti-FTA protests in India in 2009-2010.

People's movements to stop FTAs are often isolated from each other, a direct reflection of the divide and conquer strategy that bilateralism thrives on. A number of anti-FTA movements have made it a priority to break the isolation and link with others fighting such agreements in order to share analysis and learnings from each other's struggles. The Thai anti-FTA movement has been quite proactive in this respect, organizing several events which have brought activists from different countries together to strategize on FTAs (similar collaboration has also taken place in Latin America among movements fighting bilateral deals). FTA Watch, a Thai coalition, invited bilaterals.org, and GRAIN, a small international NGO with strong relationships with many social movements, to help co-organize a global strategy meeting of anti-FTA activists. The three-day "Fighting FTAs" workshop was held in July 2006 in Bangkok, bringing together around 60 social movement activists from 20 countries of Africa, the Americas and the Asia-Pacific region to share experiences in grassroots struggles against FTAs and to build international strategies and cooperation. For many, it was the first time they had been able to physically sit down with other movement activists fighting FTAs and discuss strategy and experiences. In February 2008, GRAIN, bilaterals. org, and BIOTHAI (Biodiversity Action Thailand) produced a collaborative publication and launched a multimedia website called "Fighting FTAs: the growing resistance to bilateral free trade and investment agreements" which provides both a global overview of the spread of FTAs and maps the growing resistance and learning's from people's experiences of fighting FTAs. This resource was merged into a relaunched and redesigned bilaterals.org website in 2009 which is continuously updated. The website is a collaborative information tool that also has a public and political persona. This has been a useful (though unintended) impact because it allows people to identify bilaterals.org as a collective support to social movements: no one group is behind it, it has a critical view and voice, and is an initiative people can work with and through. 


\section{Spreading Resistance against Bilateral Free Trade Agreements}

Several significant international movement networks have drawn attention to the importance of opposing bilateral free trade and investment agreements. In November 2006, the Asian Peasant Coalition (APC) issued a critique of the Japan-Philippines Economic Partnership Agreement (JPEPA) which denounced it as "a very onerous deal ... worse than the impositions by the WTO itself," and called upon the Philippine government to scrap it. Predicting that Filipino farmers would be hardest hit by the deal, the statement predicted that JPEPA would "further sink the Philippines into being a beggar state" (Asian Peasant Coalition, 2006). Starting in October 2006, militant Filipino farmers, led by the Kilusang Magbubukid ng Pilipinas (KMP), launched several protest actions at the Japanese embassy. Members of the APC have joined Filipino farmers in protest actions against JPEPA.

La Via Campesina has also made a number of statements explicitly opposing bilateral FTAs. A number of its member organizations, particularly in Central America, Korea and Africa are engaged in struggles against (mainly) US and EU-driven FTAs. In a January 2008 statement, Via Campesina members from Asia, Europe, Africa and Latin America stated that
all bilateral and bi-regional free-trade agreements, be they called "Tratados de libre-comercio" (TLC), "Free-trade agreements" (FTA) or "Economic Partnership Agreements" (EPAs), are of the same nature. They lead to the plundering of natural resources and only serve transnational companies at the expense of all the world's peoples and environment. These are not partnership agreements but Economic Plundering Agreements (Via Campesina, 2008).

The organizations demanded "that governments not sign or withdraw from these agreements."

\section{Knowledge Production, Social Movement Learning, Theory and Struggle}

FTA struggles highlight the importance of resistance firmly grounded in local and national contexts, but which connects to regional and global perspectives. Strategies that emerge from strong local organizations are the ones most able to map the terrain of struggle, to identify key local and international players pushing specific agreements and specific provisions of agreements to know their weak points, histories, styles of operating and how they are connected, and to oppose, expose and challenge those pushing FTAs and their strategies. Alongside this, technical policy analysis-something which so many advocacy NGOs prioritize - needs to be informed by and connected to the realities of people's struggles, not the other way round. These forms of knowledge are increasingly important as potential resources for other movements which find themselves confronting the same strategies and players in different countries. 
As Kelley (2002) puts it: "Social movements generate new knowledge, new theories, new questions. The most radical ideas often grow out of a concrete intellectual engagement with the problems of aggrieved populations confronting systems of oppression" (p.9). Participation in social activism offers activists and the wider movement(s) opportunities to learn and create knowledge, through informal activities that take place in the daily life of organizations/movements. As Choudry and Shragge (2011) note, this happens if the place created is not overly controlled by professionalism and offers social interaction. This "social learning" is embedded in social interaction between participants in social movements and organizing, or between organizations/movements. This learning is often unanticipated, incidental (though not insignificant), and dynamic in nature. Holst $(2002,2011)$ notes how the importance and nature of learning in social movements tends to be dismissed in the literature. For him, social movements, through public protest that can take various forms, attempt to educate and persuade the larger public and politicians. Second, there is much educational work internal to social movements, in which organizational skills, ideology, and lifestyle choices are passed from one member to the next informally through mentoring and modeling or formally through workshops, seminars, lectures, and so forth.

A wealth of knowledge can be brought forth from social struggles which in turn can inform strategy and theory. Yet relatively few attempts have been made to theorize informal learning through involvement in social action. One exception is Foley (1999), who validates and analyzes the importance of the incidental learning in a variety of social struggles. Foley argues that to do this analysis "one needs to write case studies of learning in struggle, making explanatory connections between the broad political and economic context, micro-politics, ideologies, discourses and learning" (p. 132).

Such forms of knowledge can directly challenge professionalization and technicism which permeates NGO-dominated global justice advocacy, and can help to inoculate organizations against disconnection from potential movement sites of contestation and building opposition. Novelli (2010) highlights the dialectics of strategic learning through struggle and contestation which includes incidental, formal, informal, and nonformal education. This implies an engagement in "strategic analysis, which in turn leads to strategic action, and then to intended and unintended consequences of action, and to further reflection/analysis and action" (p. 124). Foley (1999) emphasizes the importance of "developing an understanding of learning in popular struggle" (p.140). His attention to documenting, making explicit, and valuing incidental forms of learning and knowledge production in social action is consistent with others who understand that critical consciousness and theory emerge from engagement in action and organizing contexts, rather than ideas developed elsewhere being imposed on "the people" (Bevington and Dixon, 2005; Choudry and Kapoor, 2010; Kelley, 2002; Kinsman, 2006). 


\section{Conclusion}

McNally, (2002; 2010); Petras and Veltmeyer (2003, 2005), Boron (2005), Chun (2009), Desmarais (2007), Reitan (2007), and Motta and Nilsen (2011) illustrate that people's struggles against neoliberalism, including peasant movements, Indigenous Peoples, and militant trade unionists in Latin America and Asia, have continued to vigorously challenge states and transnational capital, notwithstanding increasing militarization and the use of anti-terror legislation against activists and communities of resistance over the past decade. With few exceptions, often lobbying campaigns by NGOs such as those on EPAs in Europe (Canterbury, 2010; Dür and De Bièvre, 2007), there has been relatively little activism addressing FTAs in Europe and North America. The responses of movements to bilateral FTAs in the post-9/11 climate illustrate a growing disconnect between anti-neoliberal activism in Europe and North America and the rest of the world. In many Northern activist networks, campaign focuses around the connections between imperialism, war and links to questions of political economy and neoliberal capitalism have often been limited to articulating US oil interests in the Middle East with the invasion of Iraq. Yet for many on the frontlines against FTAs in Thailand, South Korea or the Philippines, these links are often identified and articulated in a far more sophisticated manner (bilaterals.org, BIOTHAI and GRAIN, 2008; Choudry, 2009, 2010; Mathew, 2005; McNally, 2002; Petras \& Veltmeyer, 2003).

The current wave of bilateral free trade and investment agreements represent an intensification of capitalist globalization. The comprehensiveness of many FTAs has engendered the building of common fronts of struggle at national levels in many countries, but this has largely occurred outside of North America and Europe. Internationally, however, there is a tendency of NGO campaigns to be compartmentalized around individual institutions and issues (agriculture, human rights intellectual property rights, labour, women, etc). There is another tendency for a rather standard formulation or platform of opposition to be mounted by many advocacy NGOs (mainly, although not always, with actual or de facto headquarters in Europe or North America) against the WTO, the IMF and the World Bank but still relatively little focus placed on FTAs although these arguably impose more immediate threats. There remains a reticence to reconceptualize globalization to include threats outside of the global institutions such as the WTO, World Bank and IMF, and to see dangers inherent in apparently smaller deals. The question remains how to conceptualize capitalist globalization equally driven by a web of smaller agreements and to target this process in a concerted manner. In understanding the significance of many of these anti-FTA movements, the question of their success may hinge on whether they can build long-term alliances against neoliberalism rather than stopping an FTA, and sustain a critique of capitalist globalization in whatever form it may take, and as we can see with NAFTA, the US-Korea FTA and other agreements, the social struggle does not necessarily end when the deal is signed. As McNally (2002) 
and Katsiaficas (2002) contend, within "anti-globalization" networks, a disproportionate focus and awareness about the modalities of mobilizations and activism in North America and Europe lends itself to overlooking what are often far more complex, mass-based and sustained forms of resistance to capitalism and colonialism in the Third World, including new fronts of struggle against bilateral free trade and investment agreements. Since most of these mobilizations have taken place in Asia and Latin America, and with little sustained major mobilization against such deals in Northern countries, these struggles have also escaped attention in both activist and broader public circles, and scholarly attention.

In examining the knowledge being produced and shared in grounded struggles against bilateral FTAs, we can discern different forms of knowledge production and learning in struggle that can trouble disconnected transnational professionalized NGO forms of knowledge, and contribute to building a body of knowledge and resources for struggle. The fact that so much of this antiFTA resistance has happened without strong connections to transnational NGO networks is undoubtedly a factor in its relative absence from both NGO and scholarly purview. In the context of transnational social movement/ NGO networks, as Thayer (2000) notes, "barriers to South-North conceptual migration are both economic and discursive. On the one hand, the periphery and its intellectual products are constructed as both exotic and specific, while the center and its discourses and theories enjoy all-embracing, universal status" (p. 229). The privileging of Western, professionalized epistemologies of knowledge manifests itself within NGO and activist networks with the reification of "experts" and the dominance of professionalized forms of knowledge such as technical policy analysis of official texts which are decontextualized from the political and economic structures of power in which they exist. It positions certain kinds of knowledge, individuals and organizations as authoritative, and devalues or ignores others. The extent to which scholarship will attend to, arise from, and/or engage these movements and mobilizations against FTAs is unclear; yet it seems probable that, with little sign of a substantive change in today's international trade and investment policy-making to prioritize bilateral over multilateral agreements, many more such struggles will emerge.

Notes

See http://www.ourworldisnotforsale.org

Initiated in 1994, the Summit of the Americas has met a number of times to lay groundwork for a (stalled) US-led proposal for a free trade and investment agreement covering all the nations in the Americas except for Cuba - known as the Free Trade Area of the Americas.

3 The initiators included the Asia-Pacific Research Network, GATT Watchdog (New Zealand), Global Justice Ecology Project (USA), GRAIN, IBON Foundation (Philippines), XminY Solidariteitsfond (Netherlands). 


\section{References}

Asian Peasant Coalition. (2006, November 26) Critique on JPEPA, Retrieved from http://www. asianpeasant.org/archive/200611

Bevington, D. \& Dixon, C. (2005). Movement-relevant theory: Rethinking social movement Scholarship and Activism. Social Movement Studies, 4(3), 185-208.

bilaterals.org, BIOTHAI \& GRAIN (Eds.) (2008). Fighting FTAs: The growing resistance to bilateral free trade and investment agreements. London: BIOTHAI \& GRAIN. Retrieved from http://bilaterals.org

Canterbury, D.C. (2010). European bloc imperialism. Leiden: Brill.

Choudry, A. (2008). NGOs, social movements and anti-APEC Activism: A study in knowledge, power and struggle. Unpublished Doctoral dissertation, Concordia University, Montreal, Canada.

Choudry, A. (2009). Challenging colonial amnesia in social justice activism. In D. Kapoor (Ed.), Education, decolonization and development: Perspectives from Asia, Africa and the Americas. (pp. 95-110) Rotterdam: Sense.

Choudry, A., \& Kapoor, D. (Eds.). Learning from the ground up: Global perspectives on social movements and knowledge production. New York: Palgrave Macmillan.

Choudry, A. (2010). Global justice? Contesting NGOization: Knowledge politics and containment in , antiglobalization networks. In A. Choudry \& D. Kapoor (Eds), Learning from the ground up: Global perspectives on social movements and knowledge production. (pp. 17-34) New York: Palgrave Macmillan.

Choudry, A. \& Shragge, E. (2011). Disciplining dissent: NGOs and community organizations. Globalisations, 8(4), 503-517.

Chun, J. J. (2009). Organizing at the margins: The symbolic politics of labor in South Korea and the United States. Ithaca, NY: Cornell University Press.

Day, R. J. F. (2005). Gramsci is dead: Anarchist currents in the newest social movements. London: Pluto Press.

Desmarais, A. A. (2007). La Via Campesina: Globalization and the power of peasants. Halifax: Fernwood.

Dür, A. \& De Bièvre, D. (2007). Inclusion without influence? NGOs in European trade policy. Journal of Public Policy, 27(1), 79-101.

Eschle, C., \& Maiguashca, B. (2010). Making feminist sense of the global justice movement. Lanham, MD: Rowman and Littlefield.

Flesher Fominaya, C., \& Wood, L. (2011). Editorial: repression and social movements. Interface, $3(1), 1-11$.

Fighting FTAs. (2006, September). Summary Report. Fighting FTAs: An International Strategy Workshop. Bangkok, Thailand. Retrieved from www.grain.org/i/fta-bilaterals-2006-en.pdf

Flacks, R. (2004). Knowledge for what? Thoughts on the state of social movement studies. In J. Goodwin \& J. Jasper (Eds.), Rethinking social movements: Structure, culture, and emotion (pp.135-153). Lanham, MD: Rowman and Littlefield.

Flusty, S. (2004). De-coca-colonization: Making the globe from the inside out. New York: Routledge.

Foley, G. (1999). Learning in social action: A contribution to understanding informal education. London and New York: Zed Books.

Goodman, J. (Ed.) (2002). Protest and globalization: Prospects for transnational solidarity. Sydney: Pluto.

Hankyoreh. (2011, November 14). 40,000 against the KORUS FTA. Hankyoreh. Retrieved from http://english.hani.co.kr/arti/english_edition/e_entertainment/505337.html

Hewson, P. (2005). It's the politics, stupid. How neoliberal politicians, NGOs and rock stars hijacked the global justice movement at Gleneagles... and how we let them. In D. Harvie, K. Milburn, B. Trott, \& D. Watts (Eds.), Shut them down! The G8, Gleneagles 2005 and the movement of movements(pp.135-149). Leeds: Dissent! and New York: Autonomedia.

Holst, J.D. (2002). Social movements, Civil society and radical adult education. Westport, CT: Bergin and Garvey.

Holst, J.D. (2011). Frameworks for understanding the politics of social movements. Studies in the Education of Adults, 43(2), 117-127.

INCITE! Women of Color Against Violence (ed.). (2007). The revolution will not be funded: 


\section{Aziz Choudry}

Beyond the non-profit industrial complex. Cambridge, MA.: South End Press.

Institute for Agriculture and Trade Policy (IATP). (2008, July 29). Trade talks collapse, new direction needed. Press release. Retrieved from http://www.tradeobservatory.org/library. $\mathrm{cfm}$ ?refID $=103455$.

Jakarta Post. (2004, September 9). "Singapore issues" part of EU's trade agenda: Lamy. Jakarta Post. Retrieved from http://old.thejakartapost.com/yesterdaydetail.asp?fileid=20040909.N01

Juris, J. (2008). Networking futures: The movement against corporate globalization. Durham, NC.: Duke University Press.

Katsiaficas, G. (2002). Seattle was not the beginning. In E. Yuen, G. Katsiaficas \& D. Burton Rose (Eds.), The battle of Seattle: The new challenge to capitalist globalization (pp. 29-35). New York: Soft Skull Press.

Kelley, R. D. G. (2002). Freedom dreams: The Black radical imagination. Boston: Beacon Press.

Kelsey, J. (1999). Reclaiming the future: New Zealand and the global economy. Wellington: Bridget Williams Books.

Kinsman, G. (2006). Mapping social relations of struggle: Activism, ethnography, social organization. In C. Frampton, G. Kinsman, A. Thompson \& K. Tilleczek (Eds.), Sociology for changing the world: Social movements/social research (pp. 133-156). Black Point, NS: Fernwood.

La Via Campesina. (2008, January 13). No to free trade agreements, yes to food sovereignty and people's rights! Statement. Retrieved from

http://www.viacampesina.org/en/index.php?option=com_content\&view=article\&id=475:noto-free-frade-agreements-yes-to-food-sovereignty-and-peoples-rights\&catid=38:stop-freetrade-agreements \&Itemid $=61$

Martinez, E. (2000). Where was the color in Seattle? In K. Danaher \& R. Burbach (Eds.), Globalize this! The battle against the World Trade Organization and corporate rule (pp. 6481). Monroe, ME: Common Courage Press.

Mathew, B. (2005). Taxi! Cabs and capitalism in New York City. New York: New Press.

McNally, D (2010) Global slump: The economics and politics of crisis and resistance. Oakland: PM Press.

McNally, D. (2002). Another world is possible: Globalization and anti-capitalism. Winnipeg: Arbeiter Ring.

Menotti, V. (2008, July 30). Derailing Doha and the pathway to a new paradigm: How WTO's collapse clears the way to solve today's food, fuel, and financial crises. International Forum on Globalization. Retrieved from www.ifg.org/programs/derailing_doha-vmenotti-30july08. pdf

Monsanto. (2004, April 8). Written comments concerning the US-Thailand FTA submitted by

Monsanto to the Office of the US Trade Representative. Retrieved from http://www.us-asean.org/us-thai-fta/Monsanto_Comments.pdf

Motta, S., \& Nilsen, A. (Eds.). (2011). Social movements in the global south: Dispossession, development and resistance. Basingstoke: Palgrave Macmillan.

The Nation. (2006, February 8). Pennapa Hongthong "Secret" FTA details on the net. The Nation, Bangkok. Retrieved from http://www.nationmultimedia.com/2006/02/08/national/ national 20000523.php

Novelli, M. (2010). Learning to win: Exploring knowledge and strategy development in antiprivatization struggles in Colombia. In A. Choudry, \& D. Kapoor (Eds.), Learning from the ground up: Global perspectives on social movements and knowledge production (pp. 121137). New York: Palgrave Macmillan.

Novelli, M., \& Ferus-Comelo, A. (Eds.). (2010). Globalization, knowledge and labour: Education for solidarity within spaces of resistance. London: Routledge.

Petras, J., \& Veltmeyer, H. (2003). System in crisis: The dynamics of free market capitalism. Black Point, NS: Fernwood.

Polet, F., \& CETRI (2004). Globalizing resistance: The sate of struggle. London: Pluto.

Prashad, V. (2003). Keeping up with the Dow Joneses: Debt, prison, workfare. Cambridge, MA: South End.

Reitan, R. (2007). Global activism. London: Routledge.

Solnit, D. (Ed.) (2004). Globalize liberation: How to uproot the system and build a better world. San Francisco: City Lights.

Starr, A. (2000). Naming the enemy: Anti-corporate movements confront globalization. London: 
Zed Books.

Thayer, M. (2000). Traveling feminisms: From embodied women to engendered citizenship. In M. Burawoy, J. A. Blum, S. George, Z. Gille, \& M. Thayer (Eds.) Global ethnography: Forces, connections, and imaginations in a postmodern World (pp. 295-338). Berkeley: University of California Press.

Thobani, S. (2007). Exalted subjects: Studies in the making of race and nation in Canada. Toronto: University of Toronto Press.

Tujan, A., Gaughran, A., \& Mollett, H. (2004). Development and the "global war on terror." Race and Class, 46(1), 53-74.

UNICE. (2006, December 7). UNICE strategy on an EU approach to free trade agreements. Brussels. Retrieved from http://bilaterals.org/spip.php? article7265

Weintraub, S. (2003, September 3). The politics of US trade policy. Retrieved from http://news. bbc.co.uk/2/hi/business/3169649.stm

Wood, L. (2004). Organizing Against the occupation-US and Canadian anti-war activists speak out. Social Movement Studies, 3(2), 241-257.

Wood, L, (2005). Bridging the chasms: The case of Peoples' Global Action. In J. Bandy \& J. Smith (Eds.), Coalitions across borders: Transnational protest and the neoliberal order (pp.95-117). Lanham, MD: Rowman and Littlefield.

Zoellick, R. (2001, September 24). American trade leadership: What is at stake? Speech to International Institute of Economics, Washington D.C. Retrieved from

www.petersoninstitute.org/publications/papers/zoellick 1001.pdf 